\title{
Comparison of MCCG 2012 and MCCG 2017: Board Tenure and Board Independence across the Malaysian Oil and Gas PLCs
}

\author{
Dayana Mastura Baharudin (Corresponding Author) \\ Department of Accounting, School of Management \\ Universiti Sains Malaysia, Penang, 11800, Malaysia \\ E-mail: dayana.mastura@usm.my
}

Maran Marimuthu

Department of Management and Humanities

Faculty of Science and Information Technology

Universiti Teknologi PETRONAS, Tronoh, Perak, Malaysia

E-mail: maran.marimuthu@utp.edu.my

Received: September 4, 2019 Accepted: September 29, 2019 Published: October 2, 2019

doi:10.5296/bms.v10i2.15393 URL: https://doi.org/10.5296/bms.v10i2.15393

\begin{abstract}
Purpose - This study investigates the impact of the two main determinants of strengthening the independence of the board through Independent Board of Directors and Board Tenure compared between pre and post MCCG 2017.

Design/methodology/approach - The study will follow the purposive sampling method followed by descriptive statistics, regression analysis and content analysis derived from MCCG 2012 and MCCG 2017 together with previous studies to analyse the annual reports in order to explore the reporting of Board Independence and Board Tenure.

Originality/value - This study is a systematic review of recent research developments in MCCG 2012 and MCCG 2017. The Board Independence and Board Tenure scoring index
\end{abstract}


designed could also be applied to other PLCs other than the Malaysian oil and gas industry.

Keywords: Malaysian Code of Corporate Governance, MCCG 2012, MCCG 2017, Board Independence, Board Tenure, Malaysian oil and gas industry

\section{Introduction}

Currently, most organisations have realized the vital roles that autonomous managers have played since the crash of many large businesses like Enron and WorldCom. In the 1992 Cadbury Report and the 2003 Tyson Report, the significant role of non-executive directors is discussed. Berghe and Baelden (2005) examined the problem of independence as a key factor in maintaining the efficiency of the board through the management's surveillance and strategic roles.

The ultimate factor for the independence of the board is to acquire on board sufficient numbers of autonomous managers. Johari, Saleh, Jaffar and Hassan (2008) stated that the Malaysian Code of Corporate Governance's minimum structure of the independent director is still not sufficient to monitor the management. They found that earning management was not connected with the structure of the board's autonomous directors. They discovered that most companies in Malaysia had 1/3 or 33 percent of the board's autonomous managers, but it had no impact on the management of earnings. In addition, Wooi and Ming (2009) stated that in Malaysian Government Linked Companies (GLCs), the autonomous managers failed in their inner surveillance role.

Initial studies concerning board structure concentrated on the amount of autonomous board managers and while prior surveys attempted to assess the real independence (relative to the formally declared independence) of board managers, their knowledge and networking advantages, little study on tenure as a distinctive characteristic was conducted (Dou et al., 2015).

In scholarly literature, the potential effect of board tenure on board independence has not been properly studied and the public eye has fled until lately (Nili, 2015). It also revealed in the 2014 ASEAN Corporate Governance Report of the Minority Watchdog Shareholders Group that 53 out of 873 publicly listed companies have autonomous managers who have served the business for over 9 years (Abdul Razak, Mahali \& Adam, 2016).

\section{Problem Statement}

The Malaysian economy was badly hit by the Asian Financial Crisis in 1997-1998 and 10 years later the Global Financial Crisis in 2008 hit Malaysia again which created repercussions of bad management practices within organisation in order to stay afloat during the recurring crises over the years. The GDP growth rate in Malaysia had fallen from $10 \%$ to $7 \%$ as per the OECD National Accounts Data Files and the World Bank National Accounts Data during the Asian Financial Crisis (World Bank, 2016).

The workaround strategies and bad management practices were short term strategies 
practiced by organisations in order to survive the financial crisis or risk not being able to survive financially and eventually succumb to bankruptcy. These bad management practices are the causes of weak corporate governance within organisations. Companies found it hard to barely survive and recover from the first financial crisis (Asian) to be hit badly again 10 years later by the Global Financial Crisis, which resulted them in operating in any way they could in order to survive coupled with the fact that Malaysia at the time in 1998 did not have a code of Corporate Governance to govern the PLCs on Bursa Malaysia.

In the year 2000, Malaysia has implemented various initiatives including the issuance for Code of Corporate Governance to strengthen corporate governance's structure. A survey made by KPMG Fraud Survey Report in the year 2009 found out the serious problem in the corporate governance is the corporate fraud. Results indicate that in 2008 , about 88 percent of the value of fraud occurrences was attributed to inner leadership in Malaysian businesses, and the issue of corporate fraud rises 26 percent compared to 2004. This case was shown that the inner issues facing staff and management are getting worse in Malaysian businesses (Jakpar, Tinggi, Tan, Johari \& Myint, 2019).

In 2011, the Malaysian Securities Commission released the Blueprint on Corporate Governance, which established strategic measures directed at strengthening self-discipline and community which resulted in year 2012, the Securities Commission launched the Malaysian Code of Corporate Governance 2012 (MCCG 2012). In the Securities Commissions Malaysia (SC) report, it indicated that the 2012 MCCG focuses on clarifying institutions ' function in enhancing authority and governance, enhancing autonomy, and enhancing institutional efficiency and effectiveness by enhancing their structure (Securities Commission, 2012).

On the draft Corporate Governance Code 2016 (MCCG 2016), the Securities Commission Malaysia (SC) published advice. To guarantee that MCCG 2016 is in line with the business plan and market growth. Another important element of MCCG 2016, after recognizing the significance and need to improve corporate governance values, was to adopt a distinct strategy to the earlier code. The aim is to encourage the growth and focus on conduct and the outcome of the framework of corporate governance. This resulted in the birth of the Malaysian Code of Corporate Governance 2017 (MCCG 2017) (Securities Commission, 2017).

This research aims to investigate if the main issue highlighted in the launch of MCCG 2017 with regards to strengthening the board independence are implemented in the MCCG 2012 era and the MCCG 2017 era. The two main issues under the MCCG 2017's aim to strengthen the board independence are issues with Board Independence which looks at the number of independent directors and Board Tenure which looks at the duration of years independent directors may serve on the board.

\section{Research Objectives}

Following are objectives of the proposed study: 
1. To measure the disclosure level of MCCG 2012 and MCCG 2017's reflection of compliance of board independence and board tenure across Malaysian oil and gas PLCs by comparing the two Codes.

2. To investigate the impact of the disclosure extent of board independence compared between MCCG 2012 and MCCG 2017 towards the financial performance of the Malaysian oil and gas PLCs.

3. To examine the impact of the disclosure extent of board tenure compared between MCCG 2012 and MCCG 2017 towards the financial performance of the Malaysian oil and gas PLCs.

\section{Research Questions}

Following are the proposed questions of the study.

1. What is the disclosure level of board independence and board tenure during the MCCG 2012 and the MCCG 2017 era which reflects the compliance level?

2. Does the disclosure extent of board independence compared between MCCG 2012 and MCCG 2017 have impact on the financial performance of the Malaysian oil and gas PLCs?

3. Does the disclosure extent of board tenure compared between MCCG 2012 and MCCG 2017 have impact on the financial performance of the Malaysian oil and gas PLCs?

\section{Literature Review}

The MCCG proposes that one-third of the company's management board shall include autonomous managers. Many studies examined the connection between corporate governance and firm performance, especially board independence. However, the results are largely inconclusive on the relation between the independence of the Board and firm results (Terjesen, Couto \& Francisco, 2016). Prior researchers have used three theories mainly to explain such a relationship as follows:

First, agency theory describes conflicts of interest (Fama \& Jensen, 1983), both between the principal (owner) and agent (management). This theory states that companies can enhance their efficiency by having a big amount of autonomous directors on the board because such directors are external persons with no critical interest in the enterprise (Terjesen et al., 2016) and are able to monitor and advise managers who in turn can promote and impact shareholder interests (Brickley \& Zimmerman, 2010). This opinion, however, was called into question. First, autonomous managers who are generally members of various boards are very busy leading to bad corporate results (Kumar \& Sivaramakrishnan, 2008).

Secondly, CEOs cannot be influenced by autonomous managers to act on their behalf because the office is not available (Oshry, Hermalin \& Weisbach, 2010; Rashid, 2018). The theory of resource dependence focuses secondly upon the external resources provided by independent managers for their firms (e.g. knowledge, network or social resources, expertise and legitimacy). Unique experiences and expertise that other companies obtain from autonomous management companies are reported by Terjesen et al. (2016), and this resource can assist companies boost their profits and succeed. But, considering the absence of inside information 
from autonomous managers, they may not be sufficiently skilled at fulfilling their duties (Rashid, 2018).

Thirdly, the upper echelons theory illustrates that managers ' behavior, expertise and values can affect company efficiency. The authorisation of autonomous managers has been discovered to support effective surveillance and to boost firm value. Zhu, Ye, Tuger and Chan (2016.) But Hambrick (2007) asserted that managers in the boardroom could not use their knowledge and abilities. The independence of the board of directors may not enhance the efficiency of the business (Laux, 2008; Wang, Lu \& Tsai, 2011). Independent managers must therefore apply their expertise, expertise and expertise in decision-making (Adams \& Ferreira 2007).

The board's significant input is to formulate the policy of the business and to exercise adequate supervisory role throughout the activities of the business (Zinkin, 2010). Independent managers could contribute their autonomous opinions and engage actively in the debate of the board. They are going to represent shareholders on the board of the company. As an independent person, they have to ensure their presence and performance free of any insider or management influence. The business appoints autonomous managers to monitor executive managers ' performance and top managers. They would therefore promote shareholders ' interest by maximizing the importance of shareholders.

Zinkin (2010) indicated that autonomous managers should address several fields that would contribute to efficient business strategy formulation. They should ask business-related questions that the business is venturing into, product market segmentation, and precious market segmentation clients (Fuzi, Rahim and Tan, 2012).

Independent managers with appropriate industry background and broad knowledge would be more prepared to challenge Chief Executive Officers (CEOs) and the board discussion leadership team. In the structure of board members and board committees, Bursa Malaysia requires the autonomous managers. For example, most of them are autonomous, all members of the audit committee must be non-executive directors. These would safeguard the interests of shareholders from controlled leadership to guarantee autonomous managers. The 2012 Malaysian Code on Corporate Governance (MCCG) has made a number of suggestions to strengthen the independence of the company's board. The Code emphasizes the nomination committee structure, which should consist of a majority of autonomous managers. Furthermore, if the company's chairperson is not autonomous, the board's majority members must be autonomous and its autonomous directors should be reviewed annually by the board (Syed Fuzi et al, 2016).

Tenure tends to promote batches within an organisation (Pfeffer, 1983). Long tenure between managers can imply enhanced social cohesion for a board and the capacity to rapidly achieve consensus based on shared knowledge (Knudsen and Meyerson, 1992).

While long-term managers may be fully socialized to embrace the norms and values of the organisation, their level of engagement and allegiance to the organisation and its leadership IS also improved (Muth and Donaldson, 1998). 


\section{Macrothink

Therefore, social ties between leadership and autonomous board members could have an effect on the efficiency of boards conducting their advisory and tracking functions in various respects (Hoitash, 2011).

Experienced managers create industry knowledge and finesse on whose board they serve by exposing them to the strategy of the company, financing a competitive atmosphere through their lengthy tenures (Dou et al, 2015). Alternatively, the theory has been created that long board tenure can lead to the consolidation that decreases the efficiency of external managers. Long-term tenure managers are more likely to have a long-term friendly connection with leadership (Vafeas, 2003).

\section{Theoretical Framework}

\section{Agency Theory}

According to Jensen and Meckling (1976), agency relationship is established when agents, who are the managers, appointed by the principal, who is the owner of company, are given the authority to make decision on behalf of the principal. Agency problem usually occurs due to information asymmetry between owners and managers.

The agency theory argues that having at least half of the board to consist of independent directors or majority independent directors as per the recommendations in MCCG 2017 will increase the independence of the board and will improve the monitoring role of the board.

Furthermore, another tool introduced by MCCG 2017 to further strengthen the board would be the two-tier voting process by the shareholders in order to retain an independent director beyond 12 years would be in congruence with the agency theory in reducing the conflict between the principal and the agent.

\section{Proposed Conceptual Framework}

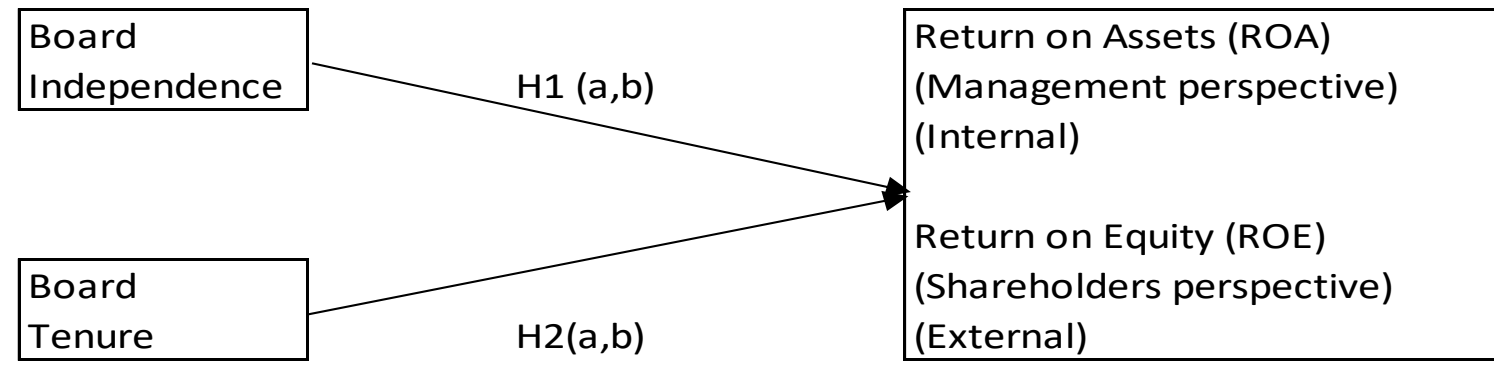

Independent

Dependent Variable

Variables

Figure 1. Proposed Conceptual Framework 
A new Malaysian Corporate Governance 2017 (MCCG 2017) was launched by the Malaysian Securities Commission Malaysia with immediate effect on 26 April 2017 and replaced MCCG 2012. The new MCCG 2017 introduced new recommendations in order to increase the level of corporate governance practices among the companies in Malaysia.

The MCCG 2017 has a different strategy through the CARE approach (abbreviated from the term 'Comprehend, Apply and Report') moving away from the 'comply or explain' method used in MCCG 2012 to the 'apply or explain an alternative' method. The new Code is thought to allow greater flexibility in the implementation of the code of best practice (Christopher \& Lee Ong, 2017).

This paper will focus on the one of the major changes in the Code which is to strengthen the independence of the Board and is discussed under two main sub-topics which are Board Independence and Board Tenure as follows:

\section{Independent Variable 1 -}

1. Board Independence:

MCCG 2012 requires that if the Chairman of the company is not an Independent Director, then the Board of Directors should consist of a majority of Independent Directors. Therefore, it was not compulsory to ensure that there is a majority of Independent Directors on the Board (Securities Commission, 2012).

MCCG 2017 now recommends that at least half of the Board of Directors must consist of Independent Directors and for Large Companies as specified by the Code, there must be a majority of Independent Directors within the Board (Securities Commission, 2017).

\section{Independent Variable 2 -}

2. Board Tenure:

MCCG 2012 discourages an Independent Director from serving more than 9 years on the Board which is also in congruence with MCCG 2017 (Securities Commission, 2012).

MCCG 2017 have tighten the rules in which the retention of an Independent Director for more than 9 years will require shareholders approval during the annual general meeting and the retention of an Independent Director for more than 12 years will require shareholders approval during the annual general meeting through a two-tier voting process: in which Tier 1 requires voting by large shareholders and Tier 2 requires voting by other shareholders.

Furthermore, large companies are discouraged from maintaining an Independent Director for more than 12 years (Securities Commission, 2017).

\section{Dependent Variable - Firm Performance (Return on Equity and Return on Assets)}

Return on equity is defined as a measure of how much the company produces for its owners, $\mathrm{ROE}$ is equivalent to net profit divided by shareholder equity's book value. The equity of the 
shareholder generally includes the value of the reserves that could be paid out to shareholders (Richard, Devinney, Yip and Johnson, 2009).

In the current literature, several indices, such as return on assets (ROA) (Huang, Oua, Chena, \& Lin, 2006 ; Khanna \& Palepu, 2000), return on equity (ROE), Tobin's Q (Habib \& Ljungqv ist, 2005 ; Khanna \& Palepu, 2000) ; market to book value ratio (MBVR) (Sarkar \& Sarkar, 2 000), return on capital employed and operating profit margin.

Indicators such as ROA and ROE are profitability measurements based on accounting, while i ndicators such as Tobin's Q and MBVR are measurements based on stock market. The measur ements based on accounting reflect past economic results, while the market-based measure fu ture performance.

If ROA were selected as an indicator of company performance then it would only explain ho w efficiently the company used the resources to produce profits, but this is not the only determinant of the well-being of the company. Other than using assets, the company also has to invest judiciously in the equity to produce greater income that will make the company's shareholders happy. This can encourage the use of equity return (ROE) as a strong performance measure. However, using ROE can be difficult.

It can distract attention from company fundamentals if investors are not cautious and lead to unpleasant surprises. Companies can resort to economic approaches to preserve a good ROE artificially for a while and conceal declining company fundamentals performance.

Growing debt leverage and inventory buybacks financed through accumulated money can assist keep the ROE of a company despite the eroding of operating profitability. Based on the balance sheet and other company financial statements, both ROA and ROE are calculated and therefore do not account for market-oriented variables. The balance sheet announcements could also affect stock market policies owing to investor expectations (Chaudhuri, Kumbhakar \& Sundaram, 2016).

\section{Hypotheses of the Study:}

Hypothesis 1(a): Board independence has positive impact on firm financial performance during the MCCG 2012 era.

Hypothesis 1(b): Board independence has positive impact on firm financial performance during the MCCG 2017 era.

Hypothesis 2(a): Board tenure has positive impact on firm financial performance during the MCCG 2012 era.

Hypothesis 2(b): Board tenure has positive impact on firm financial performance during the MCCG 2017 era.

\section{Proposed Models for Future Empirical Testing}

Against this background, and in line with the objectives of this study the following models 
are proposed for future empirical testing:

Model 1:

ROE $=\beta 0+\beta 1 B O D T E N+\beta 2 B O D I N D P+\varepsilon i t$

Whereas

ROE $=$ Return on Equity for measuring accounting performance of the Malaysian oil and gas PLCs (External perspective)

ROA $=$ Return on Assets for measuring accounting performance of the Malaysian oil and gas PLCs (Internal perspective)

BODTEN $=$ Board Tenure

BODINDP $=$ Board Independence

cit $=$ Error term

Model 2:

ROA $=\beta 0+\beta 1 B O D T E N+\beta 2 B O D I N D P+\varepsilon i t$

\section{Content Validity}

The parameter for measurement of individual items are shortlisted from different measurement techniques available in the Malaysian Code of Corporate Governance 2012 (MCCG 2012), the Malaysian Code of Corporate Governance 2017 (MCCG 2017) and prior research within the study if the Corporate Governance.

\section{Scope and Methodology of the Study and Operationalization of Variables}

The sample of the study will examine public listed companies which publish Annual Reports or Integrated Reports from a population of 916 Malaysian PLCs on Bursa Malaysia.

The data will be gathered from 2016 to 2018. This study proposes a purposive sample of 34 oil and gas public listed companies (PLCs) on Bursa Malaysia. This study proposes a descriptive statistics and regression analysis methodology and also quantitative content analysis to analyse the annual reports or integrated reports.

Year 2016 was chosen due to the fact that MCCG 2012 is still effective and matured. Year 2017 was chosen as MCCG 2017 was launched during this year and companies are in a transition to change their corporate governance practices from MCCG 2012 to MCCG 2017 and most likely that the changes introduced in MCCG 2017 will not have been implemented yet. MCCG 2018 was chosen to see the effect of the changes launched in MCCG 2017 to be taken into effect and its likely that the new Code will be gradually implemented. Therefore, 
taking these 3 years will allow the researcher the difference between the pre and post effects of MCCG 2017.

Content analysis is the most popular and widely used method in research and accounting disclosures (Zahid and Ghazali, 2015; Boesso and Kumar, 2007). Content analysis may have both qualitative and quantitative measurements. Quantitative content analysis is considered to be the more reliable analysis (Zahid and Ghazali, 2015; Day and Woodward, 2009). The current study will use the quantitative content analysis procedure.

The data coding as per the content analysis method would be based on themes, words, or items found in the data (Nilsson,2016; Collins and Hussey, 2014).

During the classification, a scoring system will be used to determine to what extent the items were reported. The scoring system was based on a review of previous studies that used content analysis in order to determine the appropriate number of points. Larsson and Ringholm (2014) and Eccles and Serafeim (2014) used four-point systems while Wang, Song and Yao (2013) used a three-point system. Boiral (2013) and Setia et al. (2015) both used two-point systems. This study will utilise a system similar to a previous research on Integrated Reporting by Nilsson (2016), to allow for some differentiation between the companies while still being a time-effective method. The system and the criteria used are shown in Table 1 and Table 2.

Table 1. A New Board Independence Scoring Index

Board Independence characteristics ( 3 items)
$* 50 \%$ of the Board are Independent Directors
$*>50 \%$ and $<70 \%$ of the Board are
Independent Directors
$*>70 \%$ and $<100 \%$ of the Board are
Independent Directors


Table 2. A New Board Tenure Scoring Index

Board Tenure characteristics (5 items)
* tenure of an Independent Director does not
exceed a cumulative limit of 9 years
* upon completion of 9 years, an Independent
Director may continue to serve on the Board
as a Non-Independent Director
*if the Board intends to retain an Independent
Director beyond 9 years it should seek annual
shareholders approval
* if the Board continues to retain the
Independent Director after the 12 th year,
the Board should seek annual shareholders'
approval through a two-tier voting process
* the Board has a policy which limits the
tenure of its Independent Directors to 9 years

\section{Significance of Study}

The proposed study is important to the public listed companies as it allows the annual report and integrated report preparers to realise the importance of preparing and collating meaningful data for stakeholders and also for internal planning use in order to remain legitimate in the eyes of the stakeholders and the general public. The implementation of the MCCG 2017 must gradually take place in year 2018 onwards to ensure the improvement of corporate governance in the PLCs.

\section{Conclusion}

This study is limited to only 1 year after MCCG 2017 was launched which is year 2018 in which future research could look into analysing the implementation beyond one year of the implementation of the Code.

One the other hand, this research will be able to see any early adoption of MCCG 2017 by large oil and gas PLCs in order to sustain corporate reputation. 


\section{References}

Abdullah, S. N. (2001). Characteristics of Board of Directors and Audit Committees. Akauntan Nasional, 14(10), 18-21.

Adams, R., \& Mehran, H. (2003). Board Structure and Banking Firm Performance, Working Paper, Federal Reserve Bank of New York.

Ahmadi, A., Nakaa, N., \& Bouri, A. (2018). Chief executive officer attributes, board structures, gender diversity and firm performance among French CAC 40 listed firms. Research in International Business and Finance, 44, 218-226. https://doi.org/10.1016/j.ribaf.2017.07.083.

Bathala, C. T., \& Rao, R. P. (1995). The Determinants of Board Composition: An Agency Theory Perspective. Managerial \& Decision Economics, 16, 59-69. https://doi.org/10.1002/mde.4090160108

Bhd. Leblanc, R., \& Gillies, J. (2003). The coming revolution in corporate governance. Ivey Business Journal Online, 68(1), 1-12. https://doi.org/10.1111/j.1467-8683.2004.00385.x

Booth, J. R., \& Deli, D.N. (1996). Factors Affecting the Number of Outside Directorships Held by CEOs. Journal of Financial Economics, 40(1), 81-104. https://doi.org/10.1016/0304-405X(95)00838-6

Cadbury, A. (1992). Report of the committee on the financial aspects of corporate governance (Vol. 1). Gee. London. https://doi.org/10.1111/j.1467-8683.1993.tb00025.x

Claessens S., Djankov, S., \& Lang, L. (2000). The Separation of Ownership and Control in East Asian Corporations. Journal of Financial Economics, 58(1-2), 81-112. https://doi.org/10.1016/S0304-405X(00)00067-2

Claessens, S., \& Fan, J. P. (2002). Corporate governance in Asia: A survey. International Review of finance, 3(2), 71103. https://doi.org/10.1111/1468-2443.00034

Crane, A., \& Matten, D. (2007). Business ethics: Managing corporate citizenship and sustainability in the age of globalization. Oxford University Press, USA.

Davis, G. F. (2005). New directions in corporate governance. Annual review of sociology, 143- 162. https://doi.org/10.1146/annurev.soc.31.041304.122249

Fama, E. F., \& Jensen, M. C. (1983). Separation of ownership and control. The Journal of Law \& Economics, 26(2), 301-325. https://doi.org/10.1086/467037

Gani, L., \& Jermias, J. (2006). Investigating the effect of board independence on performance across different strategies. The International Journal of Accounting, 41(5), 295-314. https://doi.org/10.1016/j.intacc.2006.07.009

Gospel, H. F., \& Pendleton, A. (2005). Corporate governance and labour management: An international comparison. Oxford University Press on Demand. 
https://doi.org/10.1093/acprof:oso/9780199263677.003.0001

Gregory, J. H., \& Simms, E. M. (1999). Corporate Governance: What It Is and Why It Matters?" 9th International AntiCorruption Conference. Durban, South Africa.

Grossman, R. J. (2000). Measuring up: Appropriate metrics help HR prove its worth. $H R$ Magazine, 45(1), 28-35.

Haniffa, R., \& Hudaib, M. (2006). Corporate governance structure and performance of Malaysian listed companies. Journal of Business Finance \& Accounting, 33(7-8), 1034-1062. https://doi.org/10.1111/j.1468-5957.2006.00594.x

Hermalin, B. E., \& Weisbach, M.S. (2001). Boards of directors as an endogenously determined institution: a survey of economic literature. Economic Policy Review (Federal Reserve Bank of New York), 1, 7-26. https://doi.org/10.3386/w8161

Hossain, M., Cahan, S. F., \& Adams, M. B. (2000). The investment opportunity set and the voluntary use of outside directors: New Zealand evidence. Accounting and Business Research, 30(4), 263-273. https://doi.org/10.1080/00014788.2000.9728944

Hutchinson, M. (2002). An analysis of the association between firms' investment opportunities, board composition, \& firm performance. Asia Pacific Journal of Accounting \& Economics, 9, 17-39. https://doi.org/10.1080/16081625.2002.10510598

Jagongo, A. O., \& Makori, D. M. (2013). Working Capital Management and Firm Profitability: Empirical Evidence from Manufacturing and Construction Firms Listed on Nairobi Securities Exchange, Kenya.

Jakpar,S, Tinggi, M, Tan, K.H, Johari, A., \& Myint, KT. (2019). Analysis of Corporate Governance and Firm Performance: Evidence from Malaysian Listed Companies, International Journal of Business and Social Science, 10(1).

Jensen, M. C. (1993). The modern industrial revolution, exit, and the failure of internal control systems. The Journal of Finance, 48(3), 831-880. https://doi.org/10.1111/j.1540-6261.1993.tb04022.x

Kim S, et al. (1998). Folding in vivo of a newly translated yeast cytosolic enzyme is mediated by the SSA class of cytosolic yeast Hsp70 proteins. Proc Natl AcadSci USA, 95(22), 12860-5. https://doi.org/10.1073/pnas.95.22.12860

Kumar, S., \& Ramayah. (2013). Business Research Method. Shah Alam: Oxford Fajar Sdn.

Lipton, M., \& Lorsch, J. W. (1992). A modest proposal for improved corporate governance. Business Lawyer, 48(1), 5977.

Mak, Y. T., \& Kusnadi, Y. (2005). Size really matters: Further evidence on the negative relationship between board size and firm value. Pacific-Basin Finance Journal, 13(3), 301318. https://doi.org/10.1016/j.pacfin.2004.09.002 
Malaysia Capital Market Master Plan. (2001). Securities Commission Malaysia, Financial Sector Master Plan (2001): Bank Negara Malaysia.

Mangel, R., \& Singh, H. (1993). Ownership structure, board relationships and CEO compensation in large US corporations. Accounting and Business Research, 23(1), 339-350. https://doi.org/10.1080/00014788.1993.9729902

Marn, J. T. K., \& Romuald, D. F. (2012). The impact of corporate governance mechanism and corporate performance: A study of listed companies in Malaysia. Journal for the Advancement of Science \& Arts, 3(1).

Mohammed, H., Mahenthiran, S., Rahman, R. A., \& Hamid, N. A. (2006). Agency costs that cause companies to be suspended from the Kuala Lumpur stock exchange. Journal of Contemporary Accounting and Economics, 6(1), 99-121. https://doi.org/10.1016/S1815-5669(10)70018-7

Nicholson, G. J., \& Kiel, G. C. (2007). Can directors impact performance? A case-based test of three theories of corporate governance. Corporate Governance: An International Review, 15, 585-608. https://doi.org/10.1111/j.1467-8683.2007.00590.x

Nordberg, D. (2011). Corporate governance: Principles and issues. Los Angeles: SAGE.

O’Sullivan, M. (2000). Corporate governance \& globalization. Annals, American Academy of Political Science, 570, 153-154. https://doi.org/10.1177/000271620057000112

Okpara, J. O. (2011). Corporate governance in a developing economy: barriers, issues, and implications for firms. Corporate Governance: The International Journal of Business in Society, 11(2), 184-199. https://doi.org/10.1108/14720701111121056

Park, Y. W., \& Shin, H. H. (2003). Board composition \& earning management in Canada. Journal of Corporate Finance, 185, 1-27.

Rosalina, S. (2010). Board Size, Board Composition, and Property Firm Performance. Sachs, J. (1998). Symposium on global financial markets: the post-bubble Japanese economy and prospects for East Asia. Journal of Alied Corporate Finance, 11, 16-29. https://doi.org/10.1111/j.1745-6622.1998.tb00499.x

Sunday, O. K. (2008). Corporate governance \& firm performance: the case of Nigerian listed firms.

Tippins, M. J., \& Sohi, R. S. (2003). IT competency and firm performance: is organizational learning a missing link? Strategic Management Journal, 24(8), 745-761. https://doi.org/10.1002/smj.337

Turan, U., \& Bayyurt, N. (2013). Kurumsal Yönetim, Mülkiyet Yapıs1 ve Performans [Corporate governance, ownership structure and performance].

Yermack, D. (1996). Higher market valuation of companies with a small board of directors. 


\section{Macrothink}

Business Management and Strategy ISSN 2157-6068
Journal
of
financial
economics,
40(2),
$185-211$.
https://doi.org/10.1016/0304-405X(95)00844-5

Yusoff, W. F. W., \& Alhaji, I. A. (2012). Corporate governance and firm performance of listed companies in Malaysia. Trends and Development in Management Studies, 1(1), 43-65.

\section{Copyright}

Copyright for this article is retained by the author(s), with first publication rights granted to the journal.

This is an open-access article distributed under the terms and conditions of the Creative Commons Attribution license (http://creativecommons.org/licenses/by/4.0/). 